\title{
Studi Pengaruh Rekonfigurasi Loop Scheme Terhadap Keandalan Penyulang Blakiuh dan Penyulang Panglan
}

\author{
Bagus Widyananda Yoga ${ }^{1}$, I Gede Dyana Arjana ${ }^{2}$, A.A Gede Maharta Pemayun ${ }^{3}$
}

\begin{abstract}
In Blahkiuh village the length of feeder was 78.68 km sircuit and the length of Panglan feeder was $50.84 \mathrm{~km}$ sircuit, they had substandard reliability. It is necessary to reconfiguration the feeder by using loop scheme system. In this study the writer performed the analysis by calculating SAIFI and SAIDI and the missing $\mathrm{kWh}$ before and after reconfiguration with loop scheme system. The result of Blahkiuh feeder analiysis before reconfiguration obtained 16,534 of SAIFI blackoutyear and 35,893 of SAIDI hours/year. The loss $k$ Wh energy not served was 227.640,84 $\mathrm{kWh}$ equivalent to $\mathrm{Rp} 318.718 .182,6$. Whereas in prereconfiguration Panglan feeder obtained SAIFI 23.59 blackout/year and SAIDI 87,39 hours/year. Losses $k W h$ is happened in energy not served was 238.037,009 $\mathrm{kWh}$ equivalent to Rp 364.679.835,7. The result of the analysis after reconfiguration by the loop scheme system by adding recloser at the meeting point on both were obtained 2,089 of SAIFI blackout/year in Blahkiuh feeder and 4.27 hours/year of SAIDI, the result of energy not served was 13.369.314 $\mathrm{kWh}$ equivalent to $\mathrm{Rp} 20.481 .733,86$. In Panglan feeder obtained SAIFI 1.218 blackout/year and SAIDI 1.242 hours/year, it means the energy not served was 3.880.571 kWh equivalent to $R p$ 5.945.033,22.
\end{abstract}

Intisari- Panjang penyulang Blahkiuh mencapai 78.65 kilo meter sirkuit dan panjang penyulang Panglan 50.84 kilo meter sirkuit memiliki keandalan yang di bawah standar. Maka perlu dilakukan rekonfigurasi penyulang dengan sistem loop scheme, pada penelitian ini dilakukan analisis dengan menghitung SAIFI dan SAIDI serta $k W h$ yang hilang sebelum rekonfigurasi dan sesudah rekonfigurasi loop scheme. Hasil analisis penyulang Blahkiuh sebelum rekonfigurasi didapatkan SAIFI 16,534 pemadaman/tahun dan SAIDI 35,894 jam/tahun, kerugian kehilangan $\mathrm{kWh}$ energy not served 227.640,84 $\mathrm{kWh}$ setara dengan Rp 318.718.182,6. Sedangkan pada penyulang Panglan sebelum rekonfigurasi diperoleh $S A I F I$ 23,59 pemadaman/tahun dan SAIDI 87,39 jam/tahun, kerugian kehilangan $\mathrm{kWh}$ yang dialami hasil energy not served 238.037,099 $\mathrm{kWh}$ setara dengan $\mathrm{Rp}$ 364.672.835,7. Hasil analisis sesudah rekonfigurasi loop scheme dengan menambahkan recloser pada titik pertemuan kedua penyulang didapatkan SAIFI penyulang Blahkiuh 2,089 pemadaman/tahun dan SAIDI 4,27 jam/tahun, hasil energy not served 13.369,314 $\mathrm{kWh}$ setara dengan $\mathrm{Rp} 20.481 .733,86$. Untuk penyulang Panglan didapat hasil SAIFI 1,218 pemadaman/tahun dan SAIDI 1,242 jam/tahun, hasil energy not served 3.880,571 kWh setara dengan Rp 5.945.033,22.

Kata Kunci : Loop scheme, SAIFI/SAIDI, Energy not served

\footnotetext{
${ }^{1}$ Mahasiswa, Program Studi Teknik Elektro dan Komputer Fakultas Teknik Universitas Udayana Jln. Kampus Bukit Jimbaran 80361 INDONESIA (tlp: 0361-703315; fax: 03614321;yoga_bagus26@yahoo.com)

2, 3 Dosen,Program Studi Teknik Elektro dan Komputer Fakultas Teknik Universitas Udayana, Jln. Jalan Kampus Bukit Jimbaran 80361 INDONESIA (telp: 0361-703315; fax: 03614321; e-mail: dyanaariana@ee.unud.ac.id Maharta@unud.ac.id)
}

\section{Pendahuluan}

Sistem distribusi tenaga listrik yang andal dengan kualitas yang baik sangat penting bagi kehidupan masyarakat. Pada Penyulang Blahkiuh dan penyulang Panglan sebelum rekonfigurasi loop scheme beroperasi secara radial. Sistem jaringan distribusi primer tipe radial ini nemiliki jumlah sumber dan penyulang hanya satu buah. Bila terjadi gangguan pada salah satunya maka semua beban yang dilayani akan padam, oleh karena itu tipe radial ini keandalannya sangat rendah [1] [2] [3] [4]. Gangguan berakibat fatal, terjadi pada penyulang Blahkiuh yang mengakibatkan pemadaman total lebih dari lima menit dalam satu tahun sebanyak 21 kali. Sedangkan pada penyulang Panglan mengalami gangguan dalam setahun sebanyak 25 kali, jenis gangguan yang sering terjadi akibat buruknya cuaca alam dan kelalaian pada manusia [5].

Keandalan adalah suatu keamanan sistem untuk menghindari gangguan-gangguan yang menyebabkan sebagian besar pemadaman sistem distribusi [6] [7]. Untuk Meningkatkan keandalan dan pendistribusian tenaga listrik pada penyulang perlu memperluas sistem loop scheme terhadap jaringan. Dengan sistem loop scheme ini pemulihan catu daya setelah ganguan/trip dapat cepat teratasi, sistem loop scheme ini terdiri dari recloser feeder dipasang pada masing-masing penyulang dan recloser tie dipasang pada titik pertemuan kedua penyulang. Loop Scheme adalah automatisasi sistem back-up power dengan cara pemutus beban pada lokasi yang berbeda [8].

Berdasarkan penelitian yang telah kami lakukan sesudah rekonfigurasi dapat memperkecil daerah pemadaman yang terjadi, pada penyulang Blahkiuh gangguan yang terjadi dalam kurun waktu satu tahun sebanyak 11 kali sedangkan pada penyulang Panglan terjadi gangguan sebanyak 6 kali dalam satu tahun. Dari data-data gangguan yang terjadi sesudah rekonfigurasi banyak diakibatkan oleh kelalaian pada manusia [5]. Menurunnya jumlah pemadaman, akan berakibat pada meningkat nya keandalan penyulang Blahkiuh dan penyulang Panglan.

Berdasarkan penelitian ini pengaruh rekonfigurasi loop scheme terhadap keandalan penyulang blakiuh dan penyulang panglan agar dapat menekan angka gangguan yang terjadi maka terlebih dahulu dilakukan perhitungan SAIDI/SAIFI sebelum dan sesudah rekonfigurasi pada penyulang Blahkiuh dan penyulang panglan selanjutnya menentukan nilai rekonfigurasi loop scheme terhadap besarnya nilai energy not served ( $k$ Wh tidak terjual ).

\section{TINJAUAN PUSTAKA}

\section{A. Keandalan}

Keandalan adalah menggambarkan suatu keamanan sistem untuk menghindari gangguan-gangguan yang menyebabkan 
sebagian besar pemadaman sistem distribusi seperti akibat alam (petir, angin, hujan, binatang) dan sebagian lagi kerusakan material atau peralatan [6].

Istilah keandalan (Reliability) pada sistem distribusi adalah suatu ukuran ketersediaan/tingkat pelayanan penyediaan tenaga listrik dari sistem ke pemakai/pelanggan. Ukuran keandalan dapat dinyatakan sebagai seberapa sering sitem mengalami pamadaman, berapa lama pemadaman terjadi dan berapa cepat waktu yang dibutuhkan untuk memulihkan kondisi dari pemadaman yang terjadi. Untuk tingkat keandalan tergantung dari frekuensi pemadaman SAIFI (Sistem Average Interruption Frequensi Index) indeks ini didefinisikan sebagai jumlah rata-rata kegagalan yang terjadi per pelanggan yang dilayani oleh sistem per satuan waktu (umumnya pertahun). Indeks ini ditentukan dengan membagi jumlah semua kegagalan pelanggan dalam satu tahun dengan jumlah pelanggan yang dilayani oleh sistem tersebut. Untuk lamanya pemadaman atau SAIDI (Sistem Average Interruption Duration Index) indeks ini didefinisikan sebagai nilai rata-rata dari lamanya kegagalan untuk setiap konsumen selama satu tahun. Indeks ini ditentukan dengan pembagian jumlah dari lamanya kegagalan secara terus menerus untuk pelanggan yang dilayani selama satu tahun itu [8].

\section{B. Indeks keandalan sistem jaringan distribusi}

Indeks keandalan merupakan suatau indikator keandalan yang dinyatakan dalam suatu besaran probabilitas. Sejumlah indeks sudah dikembangkan untuk menyediakan suatu kerangka untuk mengevaluasi keandalan sistem tenaga. Evaluasi keandalan sistem distribusi terdiri dari indeks titik beban dan indeks sistem yang dipakai untuk mempeoleh pengertian yang mendalam kedalam keseluruhan capaian. Indeks keandalan tersebut antara lain : SAIFI dan SAIDI [8] [9].

- Persamaan SAIFI didefinisikan sebagai berikut :

$$
S A I F I=\frac{\sum_{i=1}^{m} C i}{N} \frac{\text { pemadaman }}{\text { pelanggan }}
$$

Keterangan:

m : jumlah pemadaman dalam satu tahun

Ci : jumlah konsumen yang mengalami pemadaman

$\mathrm{N} \quad$ : jumlah konsumen yang dilayani

- Persamaan SAIDI dedefinisikan sebagai berikut :

$S A I D I=\frac{\sum_{i=1}^{m} C i . t i}{N} \frac{\text { jam }}{\text { pelanggan }}$

Keterangan :

m : jumlah pemadaman dalam satu tahun,

$\mathrm{C}_{\mathrm{i}} \quad$ : jumlah konsumen yang mengalami pemadaman

$\mathrm{t}_{\mathrm{i}} \quad$ : lamanya tiap-tiap pemadaman

$\mathrm{N} \quad$ : jumlah konsumen yang dilayani

\section{C. $k W h$ Tidak Terjual}

$k W h$ tidak terjual adalah energy not served (energi tidak tersalurkan). Artinya apabila ada gangguan atau pemadaman maka PLN tidak dapat menjual energy listrik kepada konsumen. Besarnya energy not served yang tidak bisa diselamatkan dapat dihitung dengan persamaan [10] :

Energy Not Save $=E \cdot I \cdot \sqrt{3} \cdot \cos \varphi \cdot t$
Sedangkan untuk perhitungan rupiah $k W h$ tidak terjual yaitu :

$k W h$ tidak terjual = energy not served $. \mathrm{Rp} / k W h$

Keterangan :

$\mathrm{E}$ : Tegangan pada penyulang

I : Arus (ampere)

t : Lama pemadaman

\section{METODE PENELITIAN}

Tempat penelitian dan data - data yang digunakan bersumber dari PT.PLN (Persero) Area jaringan Bali Selatan dan PT.PLN (Persero) Unit Jaringan Rayon Mengwi, yaitu pada penyulang Blahkiuh dan penyulang Panglan.

\section{A. Alur Analisis}

Langkah Penyelesaian dapat dijelaskan dengan menggunakan diagram alur (flowchat) yang disusun secara ringkas sebagai berikut :

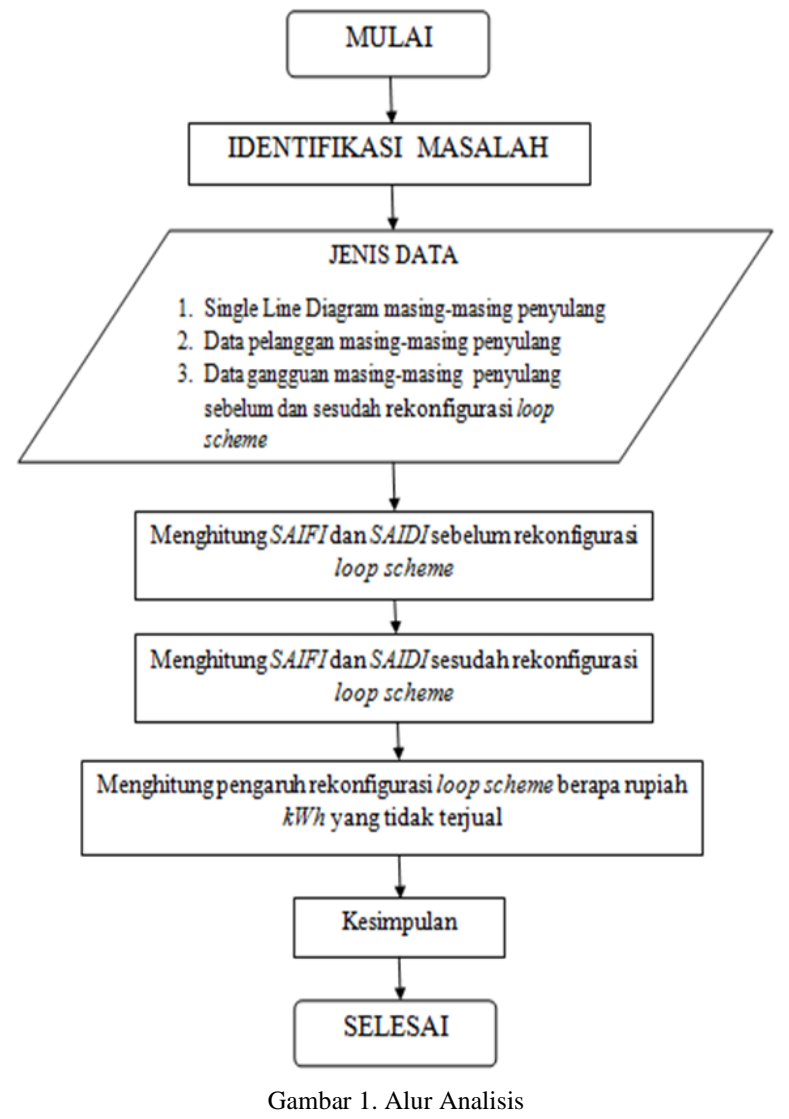

\section{a. Identifikasi Masalah}

Identifikasi masalah adalah tindakan yang dilakukan untuk mengetahui inti dari penyebab permasalahan yang ada, seperti yang terjadi pada penyulang Blahkiuh dan penyulang Panglan. Permasalahan yang ada karena kedua penyulang terlalu panjang dan seringnya terjadi gangguan yang mengakibatkan pemadaman total pada penyulang sebelum rekonfigurasi.

\section{b. Jenis Data}


Data yang digunakan dalam analisi penelitian ini adalah data sekunder yang bersumber dari PT.PLN (Persero) Area Jaringan Bali Selatan dan PT PLN Persero Unit Jaringan Rayon Mengwi dengan data-data sebagai berikut. Jenis Data adalah data-data yang digunakan untuk melakukan penelitian pada penyulang Blahkiuh dan penyulang Panglan yaitu berupa :

- Diagram segaris penyulang Blahkiuh dan Penyulang Panglan untuk membentuk rekonfigurasi sistem loop scheme.

- Data pelangggan masing-masing penyulang (total pelanggan yang dilayani oleh penyulang Blahkiuh dan penyulang Panglan).

- Data gangguan/pemadaman masing-masing penyulang sebelum dan sesudah rekonfigurasi (data ganguan/pemadaman yang digunakan adalah gangguan pada jaringan penyulang Blahkiuh dan penyulang Panglan yang di akibatkan oleh cuaca alam atau kelalaian pada manusia, selama penelitian tidak ada data pemadaman akibat perawatan jaringan) .

c. Menghitung SAIFI/SAIDI sebelum dan sesudah rekonfigurasi

Setelah didapatkan data-data yang di perlukan untuk penelitian, lalu dilakukanlah perhitungan indeks keandalan berupa SAIFI/SAIDI.

d. Sesudah didapatkan hasil perhitungan indeks keandalan SAIFI/SAIDI, dilakukanlah perhitungan energy not served/kWh tidak terjual sebelum dan sesudah rekonfigurasi loop scheme. Didapatkanlah kesimpulan berupa hasil perhitungan SAIFI/SAIDI dan energy not served dalam jangka waktu satu tahun apakah keandalan dari penyulang Blahkiuh dan penyulang Panglan meningkat/dapat memperkecil angka kerugian yang dialami PLN.

\section{HASIL DAN PEMBAHASAN}

A. Perhitungan SAIFI/SAIDI dan Energy Not Served Sebelum Rekonfigurasi Loop Scheme pada Penyulang Blahkiuh

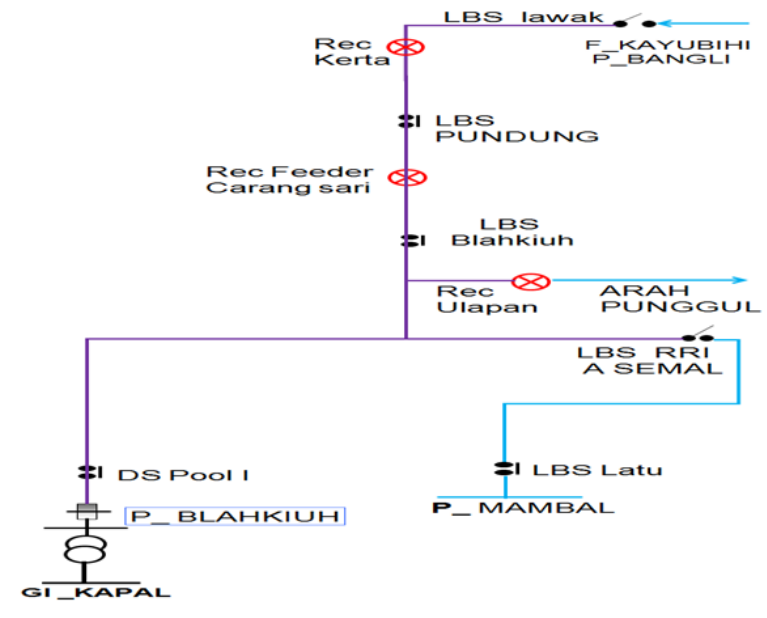

Gambar 2. Penyulang Blahkiuh menggunakan sistem radial.
Penyulang Blahkiuh termasuk jaringan terpanjang di Unit Jaringan Mengwi total panjang penyulang Blahkiuh 78.65 (kms) kilo meter sirkuit, jumlah pelanggan penyulang Blahkiuh 11.045 dengan beban yang dilayani $7.120 \mathrm{kVA}$. Sebelum rekonfigurasi penyulang Blahkiuh beroperasi secara radial.

- Data listrik padam yang terjadi pada penyulang Blahkiuh sebelum rekonfigurasi dalam jangka waktu satu tahun dapat dilihat pada tabel 1 .

Tabel 1. Data Pemadaman Pada Penyulang Blahkiuh Sebelum Rekonfigurasi

\begin{tabular}{|l|c|c|c|c|}
\hline \multirow{2}{*}{ Bulan } & \multicolumn{2}{|c|}{ PMT } & \multicolumn{2}{c|}{$\begin{array}{c}\text { Trip Recloser } \\
\text { Carang Sari }\end{array}$} \\
\cline { 2 - 5 } & Jumlah Padam & $\begin{array}{c}\text { Lama } \\
\text { Padam (jam) }\end{array}$ & $\begin{array}{c}\text { Jumlah } \\
\text { Padam }\end{array}$ & $\begin{array}{c}\text { Lama } \\
\text { Padam (jam) }\end{array}$ \\
\hline Januari & 1 & 0,18 & 1 & 1,20 \\
\hline Februari & 3 & 1,17 & 0 & 0 \\
\hline Maret & 0 & 0 & 3 & 2,69 \\
\hline April & 0 & 0 & 1 & 0,90 \\
\hline Mei & 1 & 5,64 & 0 & 0 \\
\hline Juni & 0 & 0 & 1 & 1,52 \\
\hline Juli & 2 & 6,36 & 0 & 0 \\
\hline Agustus & 2 & 3,39 & 0 & 0 \\
\hline September & 0 & 0 & 0 & 0 \\
\hline Oktober & 1 & 1,14 & 1 & 0,76 \\
\hline November & 3 & 0,45 & 0 & 0 \\
\hline Desember & 1 & 0,08 & 0 & 0 \\
\hline TOTAL & 14 & 18,41 & 7 & 7,07 \\
\hline
\end{tabular}

- Berdasarkan data pemadaman pada tabel 1 dapat dilakukan perhitungan SAIFI/SAIDI dan Energy Not Served sebelum rekonfigurasi pada penyulang Blahkiuh dalam waktu satu tahun.

Perhitungan SAIFI bulan januari sesuai rumus 1 :

$$
\begin{aligned}
S A I F I & =\frac{(1 \text { kali } \times 11.045 \text { pelanggan })+(1 \text { kali } \times 3.999 \text { pelanggan })}{11.045 \text { pelanggan }} \\
& =1,362 \text { pemadaman } / \text { pelanggan }
\end{aligned}
$$

Perhitungan SAIDI bulan januari sesuai rumus 2 :

$$
\begin{aligned}
S A I D I & =\frac{(1 \times 11.045 \times 0,18 \mathrm{jam})+(1 \times 3.999 \times 1,20 \mathrm{jam})}{11.045 \text { pelanggan }} \\
& =0,614 \mathrm{jam} / \text { pelanggan }
\end{aligned}
$$

Perhitungan Energy Not Served bulan januari sesuai rumus 3 dan 4 (harga per $k W h$ menggunakan tarif baru yang dikeluarkan dari tahun 2015 oleh PT.PLN Persero):

Energy Not Served $=\mathrm{E} . \mathrm{I} \cdot \sqrt{3} \cdot \cos \varphi \cdot \mathrm{t}($ dimana I adalah hasil pengukuran pada trafo III Blahkiuh)

$$
\begin{aligned}
& =20 \times 205,5 \times 1,732 \times 0,85 \times 0,18 \\
& =1089,133 \mathrm{kWh}
\end{aligned}
$$

Rp $k W h$ tidak terjual

$$
\begin{aligned}
\mathrm{Rp} & =\text { Energy Not Served } \mathrm{x} \text { harga per } k W h \\
& =1089,133 \times \mathrm{Rp} 1.532 \\
& =\mathrm{Rp} .1 .668 .551,75
\end{aligned}
$$

Perhitungan Energy Not Served bulan januari gangguan berada pada recloser Carang Sari : 
Energy Not Served $=$ E . I $\cdot \sqrt{3} \cdot \cos \varphi$. t. ( I arus beban yang diukur pada trafo Carang Sari saat terjadi pemadaman )

$$
=20 \times 102.7 \times 1,732 \times 0,85 \times 1,20
$$$$
=3628,678 \mathrm{kWh}
$$

Rp $k W h$ tidak terjual

$\mathrm{Rp}=$ Energy Not Served $\mathrm{x}$ harga per $k W h$

= 3628,678 x Rp 1.532

= Rp.5.559.134,69

Dengan cara perhitungan yang sama maka diperoleh nilai indeks keandalan SAIFI/SAIDI dan Energy Not Served (hasil perhitungan ENS yang dilakukan dua kali hasilnya akan di tambahkan) pada penyulang Blahkiuh sebelum rekonfigurasi loop scheme selama setahun dapat dilihat pada tabel 2.

Tabel 2. Hasil Perhitungan SAIFI/SAIDI dan Energy Not Served Penyulang Blahkiuh Sebelum Rekonfigurasi Loop Scheme

\begin{tabular}{|l|c|c|c|c|}
\hline \multicolumn{1}{|c|}{ Bulan } & SAIFI & SAIDI & $\begin{array}{c}\text { Energy Not } \\
\text { Served }(k W h)\end{array}$ & $\begin{array}{c}k W h \text { tidak terjual } \\
(\mathrm{Rp})\end{array}$ \\
\hline Januari & 1,362 & 0,614 & $4.717,811$ & $7.227 .686,44$ \\
\hline Februari & 3 & 3,51 & $21.238,104$ & $32.536 .775,33$ \\
\hline Maret & 1,086 & 2,921 & $24.402,863$ & $37.385 .186,12$ \\
\hline April & 0,362 & 0,325 & $2.721,508$ & $4.169 .350,25$ \\
\hline Mei & 1 & 5,64 & $34.126,184$ & $52.281 .313,89$ \\
\hline Juni & 0,362 & 0,550 & $4.596,326$ & $7.041 .571,43$ \\
\hline Juli & 2 & 12,72 & $76.965,438$ & $117.911 .051,00$ \\
\hline Agustus & 2 & 6,78 & $41.024,030$ & $62.848 .813,96$ \\
\hline Semtember & 0 & 0 & 0 & 0 \\
\hline Oktober & 1,362 & 1,415 & $9.196,017$ & $14.060 .712,25$ \\
\hline November & 3 & 1,35 & $8.168,501$ & $12.514 .143,53$ \\
\hline Desember & 1 & 0,08 & 484,059 & $741.578,38$ \\
\hline $\begin{array}{c}\text { TOTAL } \\
\text { Perhitungan } \\
\text { Selama }\end{array}$ & $\begin{array}{c}16,534 \\
\text { pemadaman } \\
\text { /tahun }\end{array}$ & $\begin{array}{c}35,894 \\
\text { jam/tahun }\end{array}$ & $\begin{array}{c}227.640,841 \\
k W h\end{array}$ & Rp 318.718.182,6 \\
\hline
\end{tabular}

Total nilai dari hasil perhitungan indeks keandalan SAIFI sebelum rekonfigurasi loop scheme penyulang Blahkiuh 16,534 pemadaman/tahun dan total nilai untuk indeks SAIDI 35,894 jam/tahun. Sedangkan total nilai dari hasil perhitungan energy not served selama setahun di dapatkan 227.640,841 $k W h$ setara dengan Rp.318.718.182,6.

B. Perhitungan SAIFI/SAIDI dan Energy Not Served Sebelum Rekonfigurasi Loop Scheme pada Penyulang Panglan

Penyulang Panglan juga termasuk jaringan terpanjang di Unit Jaringan Mengwi, panjangnya mencapai 50.84 kilo meter sirkuit, memiliki jumlah pelanggan 3.879 dengan beban yang dilayani 3.190 kVA. Penyulang panglan sebelum rekonfigurasi beroperasi secara radial, berikut gambar penyulang Panglan dengan sistem radial.

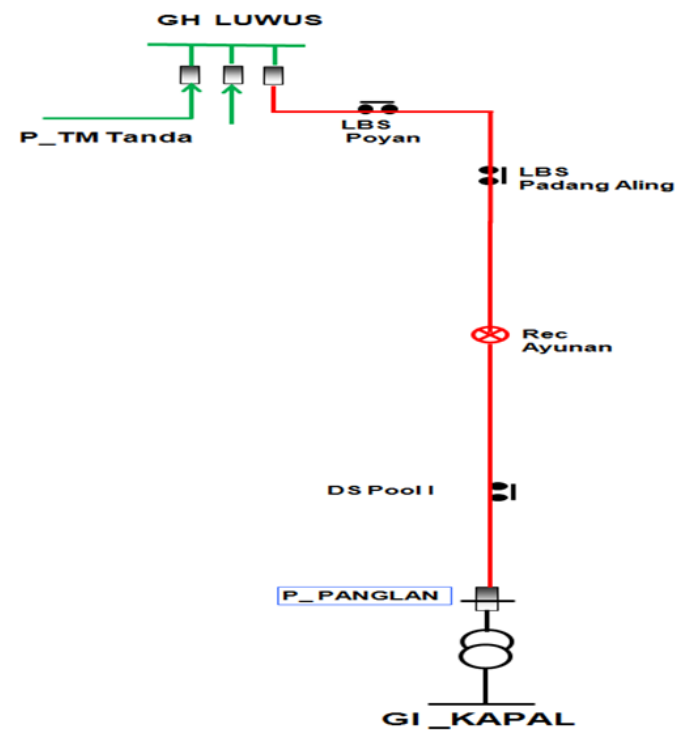

Gambar 3. Penyulang Panglan dengan sistem radial

- Data listrik padam yang terjadi pada penyulang Panglan sebelum rekonfigurasi dalam jangka waktu satu tahun dapat dilihat pada tabel 3.

Tabel 3. Data Pemadaman Pada Penyulang Panglan Sebelum Rekonfigurasi

\begin{tabular}{|l|c|c|c|c|}
\hline \multirow{2}{*}{ Bulan } & \multicolumn{2}{|c|}{ PMT } & \multicolumn{2}{c|}{$\begin{array}{c}\text { Trip Recloser } \\
\text { Ayunan }\end{array}$} \\
\cline { 2 - 5 } & Jumlah Padam & $\begin{array}{c}\text { Lama } \\
\text { Padam (jam) }\end{array}$ & Jumlah Padam & $\begin{array}{c}\text { Lama } \\
\text { Padam } \\
\text { (jam) }\end{array}$ \\
\hline Januari & 3 & 5,57 & 0 & 0 \\
\hline Februari & 4 & 6,1 & 0 & 0 \\
\hline Maret & 1 & 0,15 & 2 & 2,94 \\
\hline April & 2 & 1,28 & 0 & 0 \\
\hline Mei & 0 & 0 & 1 & 0,29 \\
\hline Juni & 4 & 4,25 & 0 & 0 \\
\hline Juli & 4 & 5,2 & 0 & 0 \\
\hline Agustus & 1 & 1,94 & 0 & 0 \\
\hline September & 1 & 0,31 & 0 & 0 \\
\hline Oktober & 0 & 0 & 0 & 0 \\
\hline November & 0 & 0 & 0 & 0 \\
\hline Desember & 2 & 0,55 & 0 & 0 \\
\hline TOTAL & 22 & 25,35 & 3 & 3,23 \\
\hline
\end{tabular}

- Berdasarkan data pemadaman pada tabel 3 dapat dilakukan perhitungan SAIFI/SAIDI dan Energy Not Served Sebelum Rekonfigurasi pada Penyulang Panglan dalam kurun waktu satu tahun.

Perhitungan SAIFI bulan januari sesuai rumus 1 :

$$
\begin{aligned}
\text { SAIFI } & =\frac{(3 \text { kali } \times 3.879 \text { pelanggan })}{3.879 \text { pelanggan }} \\
& =3 \text { pemadaman } / \text { pelanggan }
\end{aligned}
$$

Perhitungan SAIDI bulan januari sesuai rumus 2 :

$$
\begin{aligned}
S A I D I & =\frac{(3 \times 3.879 \text { pelanggan } \times 5,57 \mathrm{jam})}{3.879 \text { pelanggan }} \\
& =16,71 \mathrm{jam} / \text { pelanggan }
\end{aligned}
$$

- Perhitungan Energy Not Served bulan januari sesuai rumus 3 dan 4 : 
Majalah Ilmiah Teknologi Elektro, Vol. 17, No. 1,Januari -April 2018

DOI: https://doi.org/10.24843/MITE.2018.v17i01.P05

Energy Not Served $=$ E . I $\cdot \sqrt{3} \cdot \cos \varphi$.t $($ I adalah hasil pengukuran trafo IV yang mensuplai penyulang Panglan)

$$
\begin{aligned}
& =20 \times 276 \times 1,732 \times 0,85 \times 5,57 \\
& =45.264,850 \mathrm{kWh}
\end{aligned}
$$

Rp $k W h$ tidak terjual

$$
\begin{aligned}
\mathrm{Rp} & =\text { Energy Not Served } \mathrm{x} \text { harga per } k W h \\
& =45.264,850 \times \mathrm{Rp} 1.532 \\
& =\mathrm{Rp} 69.345 .750,2
\end{aligned}
$$

Dengan cara perhitungan yang sama maka dari hasil

\begin{tabular}{|c|c|c|c|c|}
\hline Bulan & SAIFI & SAIDI & $\begin{array}{l}\text { Energy Not } \\
\text { Served }\end{array}$ & $\begin{array}{c}\text { kWh Tidak Terjual } \\
\text { (Rp) }\end{array}$ \\
\hline Januari & 3 & 16,71 & $45.264,850$ & $69.345 .750,2$ \\
\hline Februari & 4 & 24,4 & $66.095,891$ & $101.258 .905,00$ \\
\hline Maret & 2,06 & 3,26 & $7.902,887$ & $12.107 .222,88$ \\
\hline April & 2 & 2,56 & $6.934,650$ & $10.623 .883,8$ \\
\hline Mei & 0,53 & 0,03 & 369,728 & $566.423,29$ \\
\hline Juni & 4 & 17 & $46.050,416$ & 70.549.237,31 \\
\hline Juli & 4 & 20,08 & $56.344,038$ & 86.319.066,22 \\
\hline Agustus & 1 & 1,94 & $5.255,165$ & $8.050 .912,78$ \\
\hline Semtember & 1 & 0,31 & 839,742 & $1.286 .484,74$ \\
\hline Oktober & 0 & 0 & 0 & 0 \\
\hline November & 0 & 0 & 0 & 0 \\
\hline Desember & 2 & 1,1 & $2.979,732$ & $4.564 .949,42$ \\
\hline \begin{tabular}{|c|} 
TOTAL \\
Perhitungan \\
Selama Satu \\
Tahun
\end{tabular} & $\begin{array}{c}23,59 \\
\text { pemadam } \\
\text { an/tahun }\end{array}$ & $\begin{array}{c}87,39 \\
\text { jam/tahun }\end{array}$ & $\begin{array}{c}238.037,099 \\
k W h\end{array}$ & Rp 364.672.835,7 \\
\hline
\end{tabular}
perhitungan nilai indeks keandalan SAIFI/SAIDI dan Energy Not Served selama setahun dapat dilihat pada tabel 4.

Tabel 4. Hasil Perhitungan SAIFI/SAIDI dan Energy Not Served Penyulang Panglan Sebelum Rekonfigurasi Loop Scheme

Total nilai hasil perhitungan SAIFI pada penyulang Panglan sebelum rekonfigurasi loop scheme 23,59 pemadaman/tahun dan total nilai hasil perhitungan dari SAIDI 87,39 jam/tahun. Sedangkan total nilai dari hasil perhitungan energy not served selama setahun didapatkan 238.037,099 kWh setara dengan Rp.364.672.835,7.

\section{Perhitungan SAIFI/SAIDI dan Energy Not Served Sesudah Rekonfigurasi Loop Scheme pada Penyulang Blahkiuh dan Penyulang Panglan}

Tujuan dari rekonfigurasi loop scheme adalah untuk mempercepat pemulihan tegangan setelah gangguan di sisi pelanggan. Dimana dengan terpasangnya sistem ini bila terjadi gangguan sementara/temporer pemulihan tegangan setelah gangguan di harapkan mampu dilakukan hanya dengan waktu sesingkat mungkin. Dan bila terjadi gangguan permanen pada salah satu penyulang, bisa dilokalisir dengan cara melepas saklar/pengaman yang terdekat pada beban baik berupa recloser maupun $L B S$, dengan begitu daya bisa di manuper dari penyulang lain. Tujuannya agar tidak semua pelanggan mengalami pemadaman.

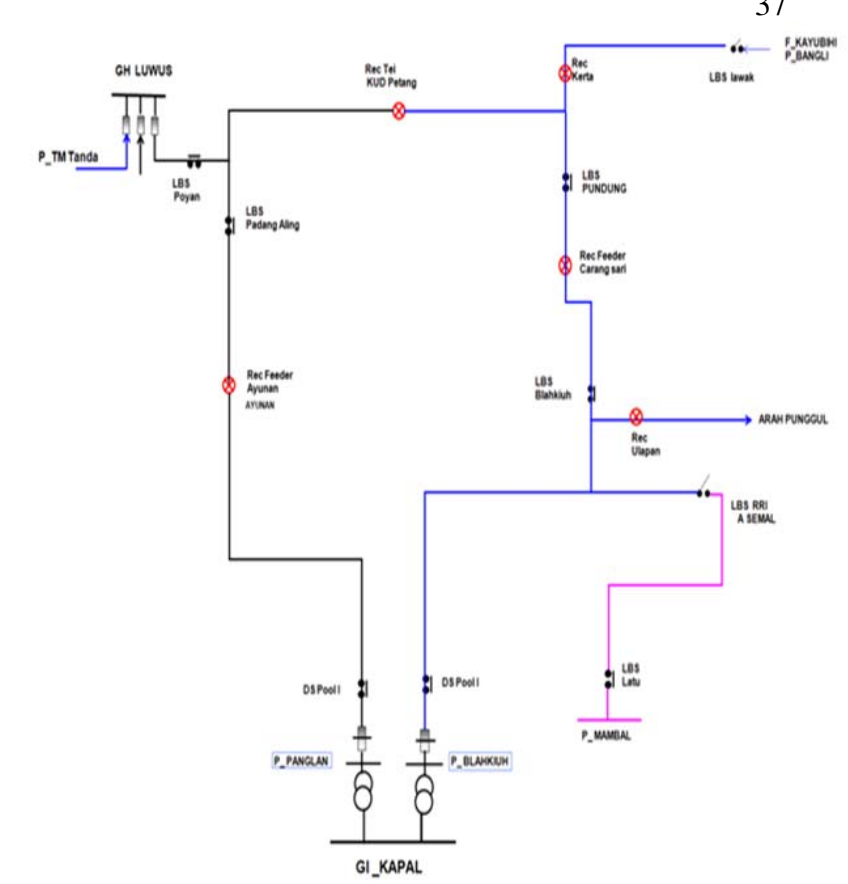

Gambar 4. Konfigurasi Loop scheme pada penyulang Blahkiuh dan penyulang Panglan

- Data listrik padam yang terjadi pada penyulang Blahkiuh sesudah rekonfigurasi dalam waktu satu tahun dapat dilihat pada tabel 5.

Tabel 5. Data Pemadaman Pada Penyulang Blahkiuh Sesudah Rekonfigurasi

\begin{tabular}{|l|c|c|c|c|c|c|c|c|}
\hline \multirow{2}{*}{ Bulan } & \multicolumn{2}{|c|}{ PMT } & \multicolumn{2}{c|}{$\begin{array}{c}\text { Trip Recloser } \\
\text { Ulapan }\end{array}$} & \multicolumn{2}{c|}{$\begin{array}{c}\text { Trip Rec.F } \\
\text { Carang Sari }\end{array}$} & \multicolumn{2}{c|}{$\begin{array}{c}\text { Trip Recloser } \\
\text { Kurta }\end{array}$} \\
\cline { 2 - 11 } & Jum- & $\begin{array}{l}\text { Lama } \\
\text { Padam } \\
\text { (jam) }\end{array}$ & $\begin{array}{l}\text { Jum- } \\
\text { lah }\end{array}$ & $\begin{array}{l}\text { Lama } \\
\text { Padam } \\
\text { (jam) }\end{array}$ & $\begin{array}{l}\text { Jum- } \\
\text { lah }\end{array}$ & $\begin{array}{c}\text { Lama } \\
\text { Padam } \\
\text { (jam) }\end{array}$ & $\begin{array}{l}\text { Jum- } \\
\text { lah }\end{array}$ & $\begin{array}{l}\text { Lama } \\
\text { Padam } \\
\text { jam) }\end{array}$ \\
\hline Januari & 0 & 0 & 0 & 0 & 1 & 2,3 & 1 & 0,34 \\
\hline Februari & 0 & 0 & 0 & 0 & 0 & 0 & 1 & 0,25 \\
\hline Maret & 0 & 0 & 0 & 0 & 0 & 0 & 0 & 0 \\
\hline April & 0 & 0 & 0 & 0 & 0 & 0 & 1 & 1,00 \\
\hline Mei & 1 & 0,32 & 0 & 0 & 0 & 0 & 0 & 0 \\
\hline Juni & 0 & 0 & 0 & 0 & 0 & 0 & 1 & 1,2 \\
\hline Juli & 0 & 0 & 0 & 0 & 0 & 0 & 0 & 0 \\
\hline Agustus & 0 & 0 & 0 & 0 & 0 & 0 & 0 & 0 \\
\hline September & 0 & 0 & 0 & 0 & 0 & 0 & 1 & 0,35 \\
\hline Oktober & 1 & 0,20 & 0 & 0 & 0 & 0 & 0 & 0 \\
\hline November & 0 & 0 & 1 & 1,25 & 0 & 0 & 0 & 0 \\
\hline Desember & 0 & 0 & 0 & 0 & 1 & 3,21 & 1 & 0,28 \\
\hline TOTAL & 2 & 0,52 & 1 & 1,25 & 2 & 5,24 & 6 & 2,84 \\
\hline
\end{tabular}

- Berdasarkan data pemadaman pada tabel 5, dapat dilikukan perhitungan SAIFI/SAIDI dan Energy Not Served sesudah rekonfigurasi pada penyulang Blahkiuh selama satu tahun.

Perhitungan SAIFI bulan januari, yang terjadi dua kali pemadaman berada pada recloser fedder Carang sari dan recloser Kerta sesuai rumus 1 :

$$
\begin{aligned}
S A I F I & =\frac{(1 \text { kali } \times 655 \text { pelanggan })+(1 \text { kali } \times 2.243 \text { pelanggan })}{11.045 \text { pelanggan }} \\
& =0,262 \text { pemadaman } / \text { pelanggan }
\end{aligned}
$$

Bagus Widyananda Yoga: Studi Pengaruh Rekonfigurasi Loop Scheme...

p-ISSN:1693 - 2951; e-ISSN: 2503-2372 
Perhitungan SAIDI bulan januari sesuai rumus 2 :

$$
\begin{aligned}
\text { SAIDI } & =\frac{(1 \times 655 \times 2.3 \mathrm{jam})+(1 \times 2.243 \times 0.34 \mathrm{jam})}{11.045 \text { pelanggan }} \\
& =1,432 \mathrm{jam} / \text { pelanggan }
\end{aligned}
$$

- Perhitungan Energy Not Served bulan januari gangguan berada pada recloser Carang Sari sesuai rumus 3 dan 4 :

Energy Not Served $=\mathrm{E} \cdot \mathrm{I} \cdot \sqrt{3} \cdot \cos \varphi \cdot \mathrm{t}$ (I hasil pengukuran dari trafo Carang Sari sampai LBS Pundung)

$$
=20 \times 22,8 \times 1,732 \times 0,85 \times 2,3
$$$$
=1.544,043 \mathrm{kWh}
$$

Rp $k W h$ tidak terjual

$$
\begin{aligned}
\mathrm{Rp} & =\text { Energy Not Served } \mathrm{x} \text { harga per } k W h \\
& =1.544,043 \mathrm{x} \mathrm{Rp} 1.532 \\
& =\mathrm{Rp} 2.365 .473,87
\end{aligned}
$$

Perhitungan Energy Not Served bulan januari gangguan berada pada recloser Kerta :

Energy Note Served $=\mathrm{E} \cdot \mathrm{I} \cdot \sqrt{3} \cdot \cos \varphi \cdot \mathrm{t}$ (I hasil pengukuran dari trafo Br.Kerta Sari sampai LBS Lawak)

Rp $k W h$ tidak terjual

$$
\begin{aligned}
& =20 \times 58,8 \times \sqrt{3} \times 0,85 \times 0,34 \\
& =589,645 \mathrm{kWh}
\end{aligned}
$$

$\mathrm{Rp}=$ Energy Not Served $\mathrm{x}$ harga per $k W h$

$=589,645 \times \mathrm{Rp} 1.532$

\begin{tabular}{|c|c|c|c|c|}
\hline Bulan & SAIFI & SAIDI & $\begin{array}{l}\text { Energy Note } \\
\text { Served ( } k \text { Wh) }\end{array}$ & $\begin{array}{c}k W h \text { Tidak Terjual } \\
\text { (Rp) }\end{array}$ \\
\hline Januari & 0,262 & 1,432 & $2.133,688$ & $3.268 .810,01$ \\
\hline Februari & 0,203 & 0,050 & 433,562 & $664.216,98$ \\
\hline Maret & 0 & 0 & 0 & 0 \\
\hline April & 0,203 & 0,203 & $1.734,251$ & $2.656 .872,53$ \\
\hline Mei & 0,311 & 0,099 & $1.032,659$ & $1.582 .033,58$ \\
\hline Juni & 0,203 & 0,243 & $2.081,101$ & $3.188 .246,73$ \\
\hline Juli & 0 & 0 & 0 & 0 \\
\hline Agustus & 0 & 0 & 0 & 0 \\
\hline Bulan & SAIFI & SAIDI & $\begin{array}{l}\text { Energy Note } \\
\text { Served ( } k W h)\end{array}$ & $\begin{array}{c}k W h \text { Tidak Terjual } \\
\text { (Rp) }\end{array}$ \\
\hline September & 0,203 & 0,071 & 606,988 & $929.905,61$ \\
\hline Oktober & 0,311 & 0,062 & 645,412 & $988.771,18$ \\
\hline November & 0,131 & 0,164 & $2.061,08$ & $3.157 .574,56$ \\
\hline Desember & 0,262 & 1,946 & $2.640,537$ & $4.045 .302,68$ \\
\hline \begin{tabular}{|c|} 
TOTAL \\
Perhitungan \\
Selama Satu \\
Tahun \\
\end{tabular} & $\begin{array}{l}2,089 \\
\text { pemadaman/ } \\
\text { tahun }\end{array}$ & $\begin{array}{c}4,27 \\
\text { jam/tahun }\end{array}$ & $\begin{array}{c}\text { 13.369,314 } \\
k W h\end{array}$ & Rp 20.481.733,86 \\
\hline
\end{tabular}

$=\operatorname{Rp} 903.336,14$

Dengan cara perhitungan yang sama maka dari hasil perhitungan nilai indeks keandalan SAIFI/SAIDI dan Energy Not Save selama setahun setelah rekonfigurasi loop scheme dapat dilihat pada table 6 .

Tabel 6. Hasil Perhitungan SAIFI/SAIDI dan Energy Not Served Penyulang Blahkiuh Sesudah Rekonfigurasi

Total hasil perhitungan SAIFI dalam satu tahun pada penyulang Blahkiuh, setelah rekonfigurasi loop scheme didapatkan 2,089 pemadaman/tahun dan total nilai hasil perhitungan SAIDI 4,27 jam/tahun. Sedangkan total nilai dari hasil perhitungan energy not served selama setahun didapatkan 13.369,314 kWh setara dengan Rp. 20.481.733,86

- Data listrik padam yang terjadi pada penyulang Panglan sesudah rekonfigurasi dalam waktu satu tahun dapat dilihat pada tabel 7.

Tabel 7. Data Pemadaman Pada Penyulang Panglan Sesudah Rekonfigurasi

\begin{tabular}{|l|c|c|c|c|}
\hline \multirow{2}{*}{ Bulan } & \multicolumn{2}{|c|}{ PMT } & \multicolumn{2}{c|}{$\begin{array}{c}\text { Trip Recloser Fedder } \\
\text { Ayunan }\end{array}$} \\
\cline { 2 - 5 } & Jumlah & $\begin{array}{c}\text { Lama } \\
\text { Padam (jam) }\end{array}$ & Jumlah & $\begin{array}{c}\text { Lama } \\
\text { Padam (jam) }\end{array}$ \\
\hline Januari & 0 & 0 & 0 & 0 \\
\hline Februari & 0 & 0 & 2 & 0,57 \\
\hline Maret & 0 & 0 & 0 & 0 \\
\hline April & 0 & 0 & 0 & 0 \\
\hline Mei & 0 & 0 & 0 & 0 \\
\hline Juni & 0 & 0 & 2 & 1,30 \\
\hline Juli & 0 & 0 & 0 & 0 \\
\hline Agustus & 0 & 0 & 1 & 1,01 \\
\hline September & 0 & 0 & 0 & 0 \\
\hline Oktober & 0 & 0 & 0 & 0 \\
\hline November & 0 & 0 & 0 & 0 \\
\hline Desember & 0 & 0 & 1 & 4,38 \\
\hline TOTAL & & & 6 & \\
\hline
\end{tabular}

- Pada tabel 7 di atas pemadaman yang terjadi sesudah rekonfigurasi pada penyulang Panglan hanya berada pada recloser fedder Ayunan dengan data tersebut dapat dilakukan perhitungan SAIFI/SAIDI dan Energy Not Served Sesudah Rekonfigurasi pada penyulang Panglan selama satu tahun.

Perhitungan SAIFI bulan februari terjadi dua kali pemadaman pada recloser fedder Ayunan sesuai rumus 1 :

$$
\begin{aligned}
\text { SAIFI } & =\frac{(2 \text { kali } \times 788 \text { pelanggan })}{3.879 \text { pelanggan }} \\
& =0,406 \text { pemadaman } / \text { pelanggan }
\end{aligned}
$$

Perhitungan SAIDI bulan februari sesuai rumus 2 :

$$
\begin{aligned}
S A I D I & =\frac{(2 \times 788 \text { pelanggan } \times 0,57 \mathrm{jam})}{3.879 \text { pelanggan }} \\
& =0,231 \mathrm{jam} / \text { pelanggan }
\end{aligned}
$$

- Perhitungan Energy Not Served bulan februari sesuai rumus 3 dan 4 :

Energy Not Served $=\mathrm{E} \cdot \mathrm{I} \cdot \sqrt{3} \cdot \cos \varphi \cdot \mathrm{t}$ (I hasil pengukuran pada trafo Ayunan penyulang Panglan )

$$
\begin{aligned}
& =20 \times 43 \times 1,732 \times 0,85 \times 0,57 \\
& =721,672 \mathrm{kWh}
\end{aligned}
$$

Rp $k W h$ tidak terjual

$$
\begin{aligned}
\mathrm{Rp} & =\text { Energy Not Served } \mathrm{x} \text { harga per } k W h \\
& =72, .672 \times \mathrm{Rp} 1.532 \\
& =\mathrm{Rp} 1.105 .601,50
\end{aligned}
$$

(Berdasarkan perhitungan kedua penyulang tersebut diatas, bila salah satu penyulang mengalami gangguan kedua penyulang tersebut tidak akan mengalami pemadaman. Misalkan penyulang Panglan terjadi gangguan pada LBS/DS 
Majalah Ilmiah Teknologi Elektro, Vol. 17, No. 1,Januari -April 2018

DOI: https://doi.org/10.24843/MITE.2018.v17i01.P05

pool I maka penyulang Panglan tidak akan mengalami pemadaman total. Karena sesudah rekonfigurasi loop scheme titik gangguan dapat dilokalisir, dengan cara melepas saklarsaklar pemutus terdekat pada beban yang mengalami ganguan. Jadi sebagian beban penyulang Panglan yang tidak mengalami gangguan dapat di suplai daya dari penyulang Blahkiuh melalui recloser tie yang berada di tengah-tengah atau titik pertemuan kedua penyulang. Begitupun sebaliknya penyulang Blahkiuh mengalami gangguan, agar tidak terjadi pemadaman total sebagian beban yang tidak mengalami gangguan dapat disuplai daya dari penyulang Panglan).

Dengan cara perhitungan yang sama maka dari hasil perhitungan nilai indeks keandalan SAIFI/SAIDI dan Energy Not Served selama setahun setelah rekonfigurasi loop scheme dapat dilihat pada table 8.

Tabel 8. Hasil Perhitungan SAIFI/SAIDI dan Energy Not Served Penyulang Panglan Setelah Rekonfigurasi Loop Scheme

\begin{tabular}{|c|c|c|c|c|}
\hline Bulan & SAIFI & SAIDI & $\begin{array}{c}\text { Energy Not } \\
\text { Served }(k W h)\end{array}$ & $\begin{array}{l}\text { kWh Tidak Terjual } \\
\text { (Rp) }\end{array}$ \\
\hline Januari & 0 & 0 & 0 & 0 \\
\hline Februari & 0,406 & 0,231 & 721,672 & $1.105 .601,50$ \\
\hline Maret & 0 & 0 & 0 & 0 \\
\hline April & 0 & 0 & 0 & 0 \\
\hline Mei & 0 & 0 & 0 & 0 \\
\hline Juni & 0,406 & 0,527 & $1.645,919$ & $2.521 .547,90$ \\
\hline Juli & 0 & 0 & 0 & 0 \\
\hline Agustus & 0,203 & 0,204 & 639,376 & $979.524,03$ \\
\hline September & 0 & 0 & 0 & 0 \\
\hline Oktober & 0 & 0 & 0 & 0 \\
\hline November & 0 & 0 & 0 & 0 \\
\hline Desember & 0,203 & 0,280 & 873,603 & $1.338 .359,79$ \\
\hline $\begin{array}{c}\text { TOTAL } \\
\text { Perhitungan } \\
\text { Selama Satu } \\
\text { Tahun }\end{array}$ & $\begin{array}{c}1,218 \\
\text { pemadaman/ } \\
\text { tahun }\end{array}$ & $\begin{array}{c}1,242 \\
\text { jam/tahun }\end{array}$ & 3.880,571 kWh & Rp 5.945.033,22 \\
\hline
\end{tabular}

Total hasil perhitungan SAIFI dan SAIDI dalam satu tahun pada penyulang Panglan setelah rekonfigurasi loop scheme didapat hasil SAIFI 1,218 pemadaman/tahun dan total nilai hasil perhitungan SAIDI 1,242 jam/tahun. Sedangkan total nilai dari hasil perhitungan energy not served selama setahun didapatkan 3.880,571 kWh setara dengan Rp. 5.945.033,22.

D. Grafik Perbandingan nilai SAIFI/SAIDI dan Energy Not Served Sebelum/Sesudah Rekonfigurasi Loop Scheme pada Penyulang Blahkiuh dan Penyulang Panglan

- Grafik perbandingan nilai SAIFI/SAIDI dan Energy Not Served sebelum dan sesudah rekonfigurasi pada penyulang Blahkiuh.

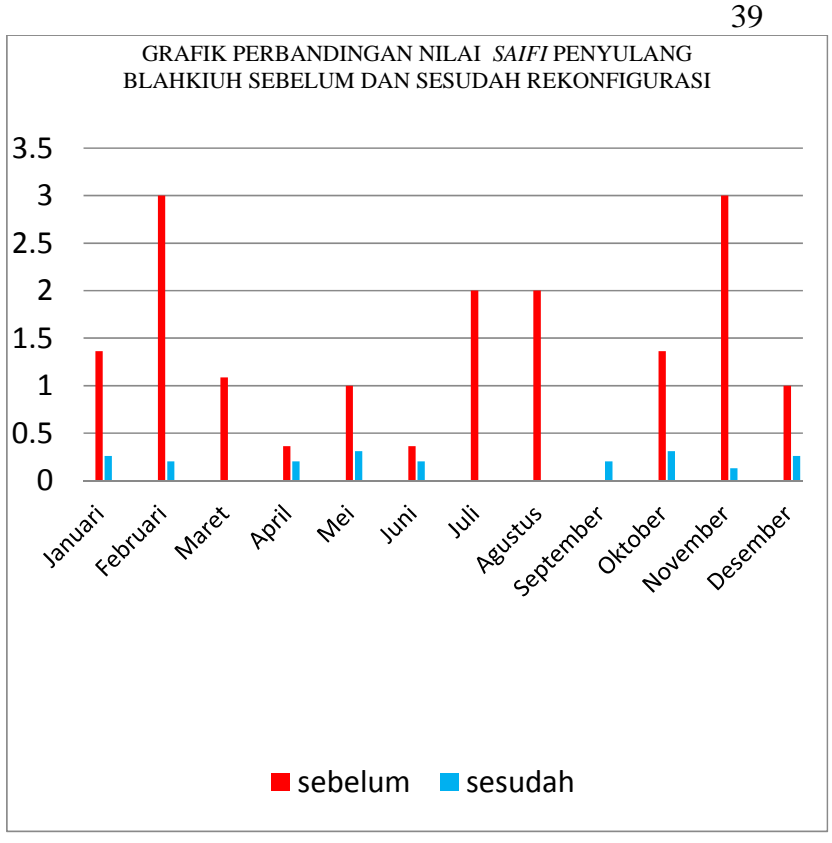

Gambar 5. Grafik Perbandingan nilai SAIFI Penyulang Blhakiuh Sebelum dan Sesudah Rekonfigurasi

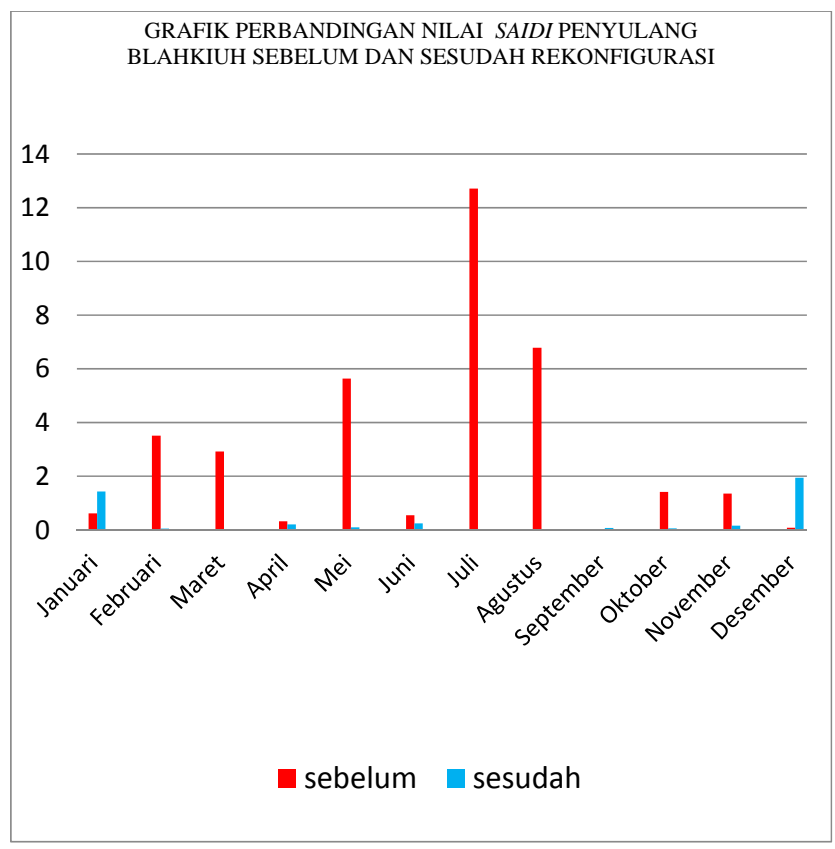

Gambar 6. Grafik Perbandingan nilai SAIDI Penyulang Blhakiuh Sebelum dan Sesudah Rekonfigurasi 


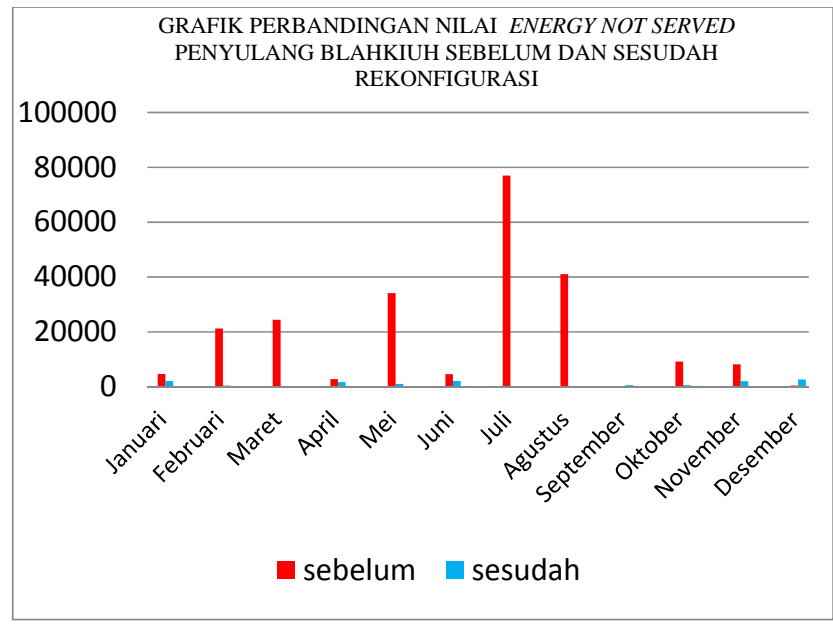

Gambar 7. Grafik Perbandingan nilai Energy Not Served Penyulang Blhakiuh Sebelum dan Sesudah Rekonfigurasi

Dari gambar 4 terlihat grafik sesudah rekonfigurasi, dapat memperkecil nilai SAIFI pada penyulang Blahkiuh dan pada gambar 5, perbandigan nilai SAIDI sesudah rekonfigurasi bulan januari dan desember lebih tinggi. Dikarenakan bulan januari terjadi gangguan jaringan tegangan menengah tertimpa bambu, penyulang Blahkiuh mengalami pemadaman 2 jam lamanya. Sedangkan pada bulan desember terjadi pemadaman 3 jam 20 menit karena saluran udara tegangan menengah pada penyulang Blahkiuh tertimpa pohon hingga tiang SUTM patah.

Menurun nya hasil nilai SAIFI/SAIDI sangat berpengaruh pada nilai Energy Not Served. Pada gambar 5 terlihat grafik Energy Not Served sesudah rekonfigurasi sangat rendah, nilai Energy Not Served setara dengan $k W h$ tidak terjual (Rp). Rendahnya nilai Energy Not Served sangat menguntungkan bagi instansi terkait yaitu PT.PLN (Persero) Area jaringan Bali Selatan dan PT.PLN (Persero) Unit Jaringan Rayon Mengwi.

- Grafik perbandingan nilai SAIFI/SAIDI dan Energy Not Served sebelum dan sesudah rekonfigurasi pada penyulang Panglan.

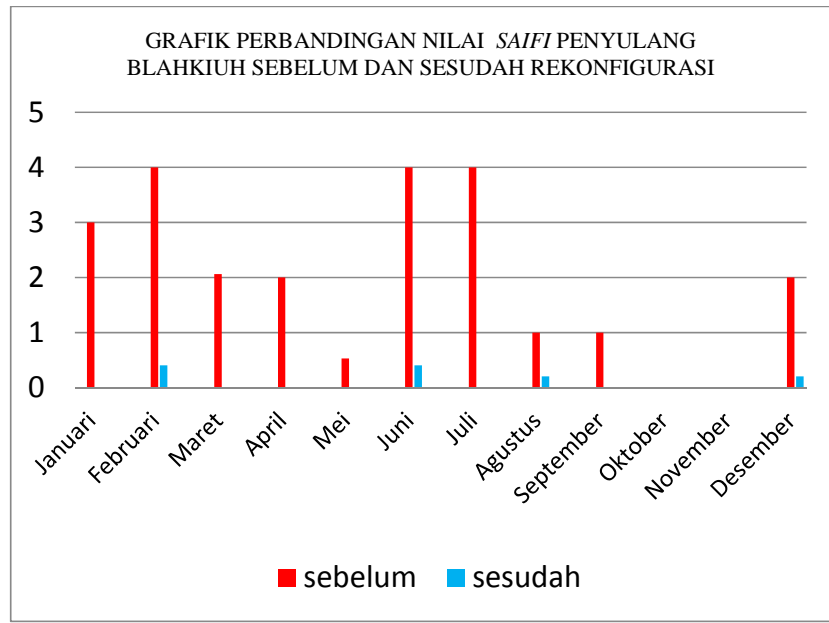

Gambar 8. Grafik Perbandingan nilai SAIFI Penyulang Panglan Sebelum dan Sesudah Rekonfigurasi

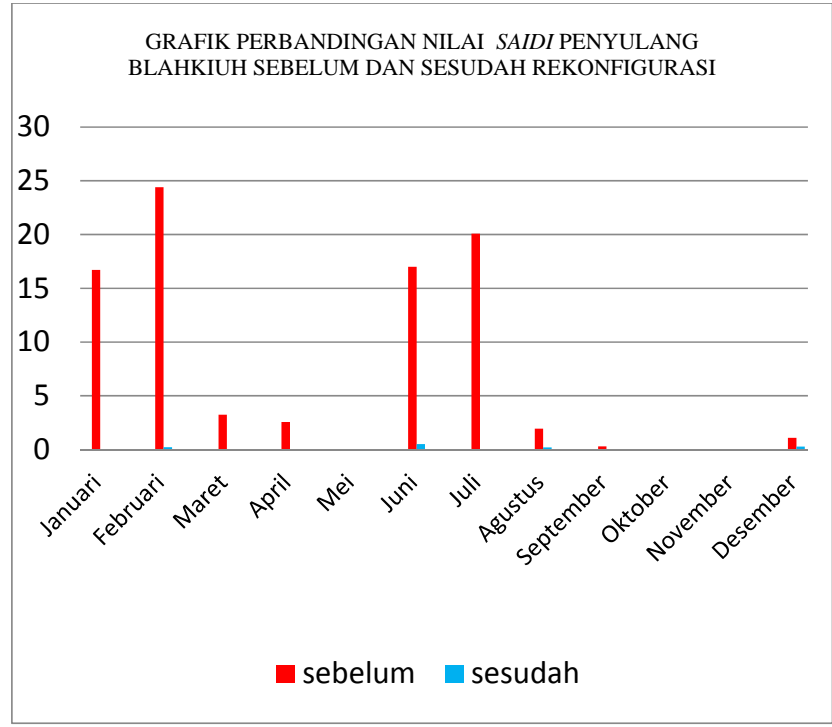

Gambar 9. Grafik Perbandingan nilai SAIDI Penyulang Panglan Sebelum dan Sesudah Rekonfigurasi

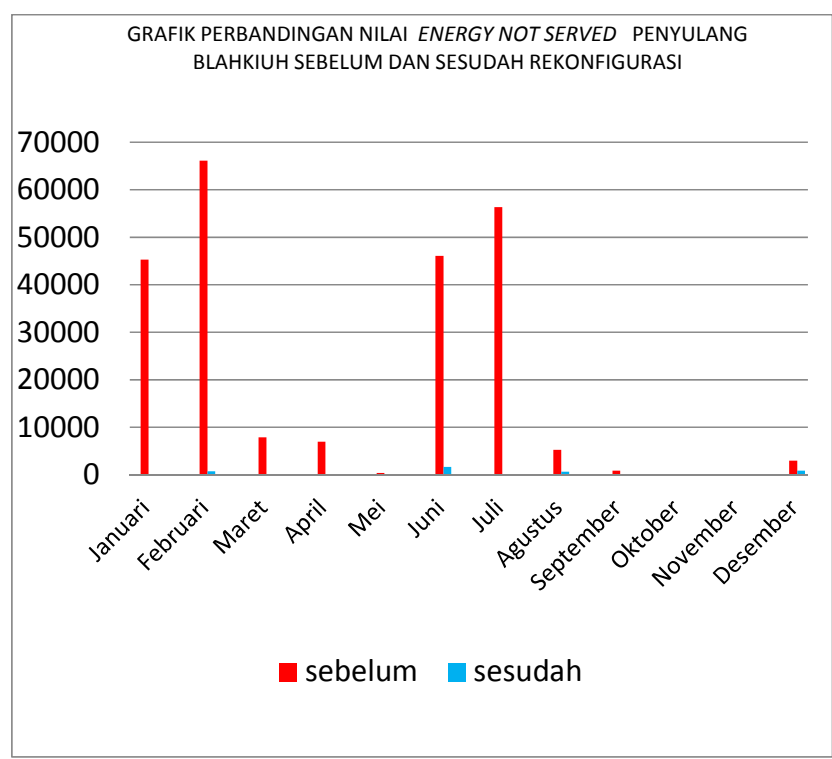

Gambar 10. Grafik Perbandingan nilai Energy Not Served Penyulang Panglan Sebelum dan Sesudah Rekonfigurasi

Berdasarkan gambar grafik 7, 8 dan 9 yaitu perbandingan nilai SAIFI/SAIDI dan Energy Not Served sebelum rekonfigurasi, angka gangguan dan lama nya pemadaman yang terjadi sangat tinggi. Dihitung dari nilai Energy Not Served sebelum rekonfigurasi, tingginya angka kerugian yang dialami berupa $k W h$ tidak terjual dalam nilai rupiah. Terlihat pada grafik sesudah dilakukan rekonfigurasi pada penyulang Panglan, dapat meminimalisir gangguan yang terjadi, dengan menurunnya nilai SAIFI/SAIDI akan berpengaruh pada nilai Energy Not Served. Jadi akan sangat menguntungkan bagi instansi terkait PT.PLN (Persero) Unit Jaringan Rayon Mengwi dapat menjual rupiah $k W h$ lebih banyak kepada pelanggan.

\section{KESIMPULAN}

1. Dari hasil perhitungan SAIFI dan SAIDI sebelum rekonfigurasi pada penyulang Blahkiuh dan penyulang 
Panglan, diperoleh hasil SAIFI penyulang Blahkiuh16,534 pemadaman/tahun dan hasil SAIDI 35,894 jam/tahun, sedangkan untuk penyulang Panglan diperoleh hasil SAIFI 23,59 pemadaman/tahun dan hasil SAIDI 87,39 jam/tahun. Sesudah rekonfigurasi pada penyulang Blahkiuh didapat hasil SAIFI 2,089 pemadaman/tahun dan hasil SAIDI 4,27 jam/tahun. Pada penyulang Panglan didapat hasil SAIFI 1,218 pemadaman/tahun dan hasil SAIDI 1,242 jam/tahun.

2. Hasil perhitungan Energy Not Served pada penyulang Blahkiuh sebelum rekonfigurasi didapat hasil energy not served 227.640,841 kWh setara dengan Rp 318.718.182,6, sedangkan pada penyulang Panglan hasil energy not served 238.037,099 kWh setara dengan Rp 364.672.835,7. Sesudah rekonfigurasi pada penyulang Blahkiuh dan penyulang Panglan diperoleh hasil energy not served penyulang Blahkiuh 13.369,314 kWh setara dengan Rp 20.481.733,86, sedangkan pada penyulang Panglan hasil energy not served 3.880,571 $\mathrm{kWh}$ setara dengan Rp 5.945.033,22. Setelah dilakukan rekonfigurasi loop scheme keandalan penyulang Blahkiuh dan penyulang Panglan meningkat, dengan menurunnya hasil SAIFI dan SAIDI serta Energy Not Served.

\section{REFERENSI}

[1] PT PLN (Persero). 2010. Kriteria Disain Enjinering Konstruksi Jaringan Distribusi Tegangan Listrik. Jakarta Selatan.

[2] Gonen,T. 1998. Electric Power Distribution System Engineering. USA: McGraw-Hill Education.

[3] Rahmat, G.S, Penangsang. O, Hernanda, IGN. S. 2013. Evaluasi Indeks Keandalan Sistem Jaringan Distribusi $20 \quad$ kV di Surabaya Menggunakan Loop Restoration Scheme. Jurnal Institut Teknologi Sepuluh November. Vol, 2. No 2.

[4] Darmahesta, I. M.W, Giriantari, IA. D, Sukerayasa, I.W. 2014. Analisis Tingkat Keandalan Sistem Suplai Distribusi $20 \mathrm{kV}$ Universitas Udayana Denpasar. Majalah Ilmiah Teknologi Elektro. Vol 13, No 1.

[5] PT PLN (Persero) Unit Jaringan Rayon Mengwi. 2013. 2015. Data Gangguan Penyulang Blahkiuh dan Penyulang Panglan. Kapal Mengwi.

[6] Sulasno. 2001. Teknik dan Sistem Distribusi Tenaga listrik. Semarang : Badan Penerbit universitas Diponogoro.

[7] Hartati, R. S, Sukerayasa, I.W, Setiawan I. N, Ariastina W. G. 2007. Penentuan Angka Keluar Peralatan Untuk Evaluasi Keandalan Sistem Distribusi Tenaga Listrik. Majalah Ilmiah Teknologi Elektro. Vol 13, Vol 1.

[8] SPLN 59, 1985. Keandalan Pada Sistem Ditribusi 20 kV dan 6 kV. Jakarta : PT. PLN (Persero).

[9] Penangsang, O. 2015. Evaluasi Indeks Keandalan Sistem Jaringan Distribusi 20 kV. Surabaya : Jurusan Teknik Elekto Fakultas Teknologi Industri, Institut Teknologi Sepuluh Nopember.

[10] Wahyudi SN. 2011. Buku Saku Pelayan Teknik (Yantek). Bekasi : Garamond 